\title{
The Function of Repetition in Trump's Inaugural Address A discourse analysis study
}

\section{Assist. Lect.Habeeb M. Areef Al-Saeedi}

College of Education/University of Al-Qadissiyah

Email: habeeb.alsaeedi@qu.edu.iq

\section{ABSTRUCT}

Political speech might be one of the most problematic types of discourse because it is usually characterized by the use of different techniques and strategies that allow politicians to convey their political messages and persuade people of their ideologies and thoughts.

The American presidential inaugural addresses are a form of political discourse that shares the characteristics of both oral and written discourse. It is actually an ample area that worth to be studied to explore some of the features that characterize this type of discourse.

This paper is an attempt to investigate the function of repetition in Trump's Inaugural address from a discourse analysis perspective.

The analysis revealed that repetition is used as a main strategy in Trump's address to reflect inclusiveness and create a shared responsibility with the audience.

Keywords: Donald J. Trump, political discourse, inaugural address, inclusiveness, 


\section{العــــــد الثامن والعشرون}

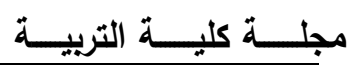

1. Introduction

Repetition is not only designed for the sake of language style, but it is used to serve different political purposes. The occurrence of different types of repetition in Trump's speech shows that language can easily be manipulated not only to demonstrate his stylistic command as a political speaker, but also to convey his political ideologies and views that may have an immediate impact on the audience.

This paper is a discourse analysis study which is more concerned with investigating the function of pronominal, phrasal and clausal repetition that Donald J. Trump employed in his speech.

The current study is divided into two parts; the first is devoted to the theoretical framework. It involves three sections: Section one provides a description of the political discourse as one of the recent and problematic areas of discourse. Section two presents the American inaugural addresses as a political discourse. Section three discusses the function of repetition in political discourse.

On the other hand, the second part provides a discourse analysis of Trump's inaugural address that he delivered on January $20^{\text {th }}, 2017$ on the occasion of his investiture in office as the $45^{\text {th }}$ president of the USA. The analysis mainly focuses on the pronominal, clausal and phrasal repetition as they are salient features in Trump's speech.

Finally, the conclusion sums up the results of this study.

\section{Theoretical background}

\subsection{Political discourse analysis:}

First of all, it seems crucial to state that the word "discourse" refers to the different patterns of language that people use in the various domains of their social life. Discourse, as Jørgensen and Phillips (2002:1) define it, is "a particular way of talking about and understanding the world (or an aspect of the world)" (italic in origin). Discourses usually involve more than the language itself. "They always involve coordinating language with ways of acting, interacting, valuing, believing, feeling, and with bodies, clothes, non-linguistic symbols, objects, tools, 


\section{العـــــــد الثامن والعشرون}

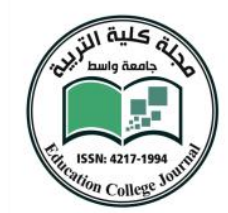

technologies, times, and places"( Gee,1999:25). He also adds that all these things are like connected threads; if one is pulled on, we may get all the others.

The political discourse, according to (Van Dijk,1997:18), is "[o]bviously a specific example of political action and interaction". In other words, It is the study of talk and text of professional politicians like presidents, prime ministers...etc. Similarly, Fairclough (1992:89) sees political discourse as a social action that shapes and is shaped by the world around us. Furthermore, political discourse is "a dynamic linguistic and, above all, semantic space in which [political] meanings are produced or challenged" (Seidel,1985:44). Hence, political discourse, whether it is a spoken or written, is a form of text. Therefore, an analysis of discourse, is an analysis of fragmented pieces of information.

According to Wilson(2003:400), George Orwell, in his article "Politics and the English Language" published in 1968, was the first who drew the attention to the political potential of language. Meanwhile, Chilton (2004) notes that the interest in the area of political discourse started growing up in the early 1980s.

Language in political discourse, as (Fairclough,1992: 89) maintains, can easily be manipulated to express the speaker's ideological beliefs and ideas as they can find their way into a text through the structure of the sentences and the selection of the words. Therefore, political discourse analysis does not look at isolated sentences or words; it looks at the context or the reflected forms of the words that carry the political message (Wilson, 2003:409).

Previous studies on political discourse (e.g. Campbell and Jamieson,1985; Allen, 2007;Wen Lin, 2011) confirm that there are always some important purposes beyond the political speeches conducted by politicians on different occasions. They are used to convince people of the speaker's political views and ideas, and to change ideologically their attitudes or believes.

So, political speeches particularly the presidential inaugural addresses, which are the concern of this paper, should be delivered in a more formal speech style. They can be authored by a specialized and professional speech writer other than the speaker (Allen,2007: 2). 


\section{العـــــــد الثامن والعشرون}

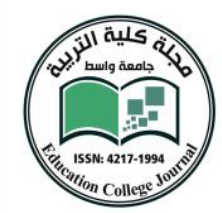

2.2. The American Presidential Inaugural Addresses as a Political Discourse

According to Liu (2012:2407), the American Presidential Inaugural Addresses "are commonly recognized as the representative of English political speaking". Similarly, Kaufer et. al., (2004:221) argue that the presidential inaugural address is "one of the most carefully crafted textual genres in politics". Campbell and Jamieson (1985:395) state that

[p]residential inaugurals are epideictic speeches because they are delivered on ceremonial occasions, fuse past and future in present contemplation, affirm or praise the shared principles that will guide the incoming administration, ask the audience to "gaze upon" traditional values, employ an elegant, literary language, and rely on "heightening of effect,".

Moreover, the presidential inaugural addresses are designed to unify the audience since they all listen to the speech of the person they have chosen for the highest executive position, and who will lead the country during the upcoming four years.

Without the presence of "the people," the rite of presidential investiture cannot be completed. The people ratify the president's formal ascent to power by witnessing his enactment of his role, acknowledging his oath, and accepting the principles he lays down to guide his administration (Campbell and Jamieson, 1985:397).

However, the presidential inaugural address is not required by the American Constitution. Rather, it is a tradition set by the first president of the USA George Washington. It is made every four years by the newly elected president to sign the beginning of a new administration. Hence, the presidential inaugural address can be seen as an extension of the oath through which the newly elected president is invested in the presidency office (Liu, 2012:2409).

Accordingly, the inauguration ceremony is a rite of transition of power from one party to another or from one administration to another. This ceremony is therefore considered to be an occasion for the new elected president to announce the principles that will govern his/her tenure in office and to persuade people that $\mathrm{s} / \mathrm{he}$ is fit to play the assigned political role and to achieve his political program objectives. At the same time, It can be seen as a "call for support and loyalty to the political regime" (Liu, 2012:2409). 
The inaugural address serves certain functions that can be reflected through the speech itself. It is mainly used to convince the audience with the speaker's point of view by using different techniques.

Many studies that have been achieved in this area mainly focused on stylistics, rhetorical devices and so on. The current study is designed to investigate the function of repetition in Trump's speech delivered on January $20^{\text {th }}, 2017$.

\subsection{The function of repetition in political discourse}

According to (Kim, 2002:53), repetition in discourse has widely been studied by many researchers such as (Kawin,1972; Johnstone, 1994; Tannen,2007).

The common meaning of repetition is "the fact of doing or saying the same thing many times." (Oxford Dictionary, 2009). Farghal and Shunnaq (1999:136) define repetition as a semantic phenomenon which refers to repeating words, phrases and sentences more than necessary to clarify a term or concept. It is a central and important notion to understand the individuals and their representation. Similarly, Kawin (1972:1) points out that repetition is a "fundamental, automatic, pervasive, and infinitely useful linguistic strategy". Further, repetition for Johnstone (1994:27) is a figure of speech that can be employed to create a marked structure with a special rhetorical effect.

Repetition in discourse, as reported by Halliday and Hasan (1976: 592), "serves as a cohesive agent, linking new utterances to previous ones through the use of repeated words, phrases or sentences". In the same vein, Tannen (2007:6062) argues that cohesion can be seen as the most apparent and straightforward way but not the only function of repetition. It evidences the speaker's attitude, participates in the organization of ideas and contributes to the meaning of the discourse. She also adds that repetition is a "vital part that gives discourse a character of familiarity and makes it sound right".

Likewise, repetition might be seen as a method that can be employed to achieve emphasis or rhythm in the developing of ideas because it implies repeating sounds, words, expressions and clauses that can be used to give a logical emphasis to the utterance and/or to show the speaker's emotional state (Jasim and Aziz, 2007:5). 
In some cases, words, phrases or sentences are repeated for the sake of producing a stylistic or poetic effects. That's to say, repetition can be employed to achieve certain textual functions. In addition, as a flexible device that adds more excitement and pleasure, repetition could be used to increase the audience's understanding (Nodelman,1994:233). In other words, it gives emphasis to some important points in a speech in order to integrate them in the brains of listeners.

In political speech, repetition, as Johnstone (1994:6)points out, enables speakers to speak fluently and efficiently; they repeat words to influence the audience feeling. In other terms, repetition could be used as a persuasive strategy that might have an important emotional impact on the audience. Hence, repetition is undoubtedly an ample strategy that allows politicians to achieve certain functions; to present themselves in a positive way and to justify their actions and to generate specific political effects on the audience.

\section{Data and Methodology}

The data of this paper includes the presidential inaugural address of the $45^{\text {th }}$ president of the USA, Donald J. Trump, which is delivered on January $20^{\text {th }}, 2017$ in Washington DC. The source of both video and transcript of the speech is http://edition.cnn.com/2017/01/20/politics/trump-inaugural-address/.

On the other hand, the analysis of Trump's speech is conducted by using the discourse analysis approach in light of Tannen's (2007) framework of repetition in discourse.

\section{Analysis and discussion}

On the inauguration day, Trump delivered his presidential inaugural address to officially announce that he will take up the responsibility as the president of the highest executive authority in the country for the next four years.

Trump's address is characterized by the use of repetition as a main strategy to organize his speech. He deploys different types of syntactic repetition such as repeating words, phrases and clauses. This section deals with three types of repetition; pronominal, phrasal and clausal repetition which are extensively employed in Trump's speech; 


\subsection{Pronominal repetition}

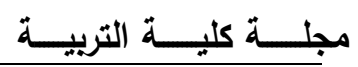

As far as the pronominal repetition is concerned, Table (1) below shows the frequency of the pronouns used in Trump's inaugural address.

\begin{tabular}{|c|c|c|c|c|}
\hline We and its variants & You and its variants & They and its variant & Others $(\boldsymbol{I})$ & Total \\
\hline 95 & 19 & 5 & 3 & 122 \\
\hline
\end{tabular}

\section{Table 1: Repetition of pronouns}

By manipulating pronouns, politicians present subtle social meanings that can be related to their multifaceted social identities. In other words, politicians use pronouns to "indicate, accept, deny or distance themselves from responsibility for political action; to reveal ideological bias; to encourage solidarity; to designate and identify those who are supporters [...]"(Wilson,1990:76). Thus, the pronominal choice may indicate to the speaker's varied identities, more specifically his/her individual or collective identity (Bramley, 2001:263). The pronominal repetition is extensively employed in Trump's speech to serve certain functions.

\section{a. The inclusiveness and shared responsibility}

In a speech consists of 1467 words, the first-person plural pronoun we and its variants being the most repeated words; their occurrence reaches 95 . This might be attributed to the inclusiveness that Trump tries to make a prominent feature in his address. In this speech, the pronoun we is used as a generic one. The generic we has the broadest scope of reference since it refers to the whole American nation.

After expressing gratitude to the electorates and his predecessors, Trump starts his speech by using the first-person plural inclusive priming strings as he says in example (1) below:

1. "We, the citizens of America, [...].Together, we will determine the course of America and the world for years to come".

"We will face challenges. We will confront hardships. But we will get the job done”(Trump,2017).

This employment is probably designed to bring the audience into his vision and to establish a collective identity and shared responsibility with the audience. 
The first-person plural pronoun we, as (Wales,1996 and Bramley, 2001) argue, is very useful for political purposes. It can be used to refer to a "collective identity or group membership" (cited in Allen, 2007: 9). It also gives the speakers the right to speak on behalf of their party, group and nation. By using we, politicians deflect the individual responsibility and make it shared around. Furthermore, the pronoun we is an effective tool to "invoke a general collective response or attitude to a matter" (ibid).

By using the inclusive $\boldsymbol{w e}$ throughout his speech, Trump always reminds his audience that he is one of them like any other citizen. The pronoun $\boldsymbol{w e}$ is used to invoke a collective identity and a group membership, rather than speaking as an individual.

A second example on the first person plural pronoun's employment can be found in (2)below:

2. "whether we are black or brown or white, we all bleed the same red blood of patriots, we all enjoy the same glorious freedoms, and we all salute the same great American Flag" (Trump,2017).

The pronoun we is used here, as Wales (1996:125) refers to, as the "patriotic we" because Trump talks about some shared characteristics by all the American citizens. It is used as a unification strategy to establish solidarity with the listeners. The employment of the pronoun we in this context is designed to tell the audience that they are one social group though they are different in term of their race, color and religion.

This usage, as Gastil (1992:484-485) argues, enables politicians to get the audience involved in their argument. It is a strong approach to create and reinforce solidarity. Thus, Trump uses the pronoun we, as a unification strategy, to bring the whole nation together.

Furthermore, Politicians have a high tendency to use the pronoun we in order to give a sense of collectivity, create involvement and shared responsibility with the audience (Karapetjana, 2011:43). This might be clearly reflected in the repetition of the first-person plural pronoun we as demonstrated in example (3) below: 
3. "We will bring back our jobs. We will bring back our borders. We will bring back our wealth. And we will bring back our dreams" (Trump,2017).

Trump, In (3), tries to get the audience support and agreement for his ideas and thoughts and to invite applause. The pronoun we appears as one of the discourse strategies that Trump relies on to persuade his audiences and get support for his political views and actions.

Moreover, the possessive pronoun our, in (3) above, links back to the preceding sentence. It is used to emphasize and reinforce the inclusiveness established by the pronoun we. It also seems as a call for the Americans to support Trump's Administration as it became their legal representative to get back their jobs, borders, wealth and dreams. The possessive pronoun our is mostly used throughout Trump's speech to emphasize his inclusiveness as well as to reinforce his argument and make it stronger.

Trump overuses the possessive pronoun our to convey a message of unity. The our, like the we, is extensively used to establish a collective membership and shared responsibility through the audience with the whole nation. In example (4) below, Trump represents himself and his administration not only as politicians but also as members of this nation who share everything in this country.

4. "We are one nation -- and their pain is our pain. Their dreams are our dreams; and their success will be our success. We share one heart, one home, and one glorious destiny" (Trump 2017).

The possessive pronoun our in (4) is used as a unification strategy and a call for all citizens in the country to rally behind their new government to overcome pain, realize dreams and achieve success. The occurrence of the word "one" which is repeated three times in the sentences that follow enhances this assumption and indicates that the whole nation should be unified to face challenges and achieve success.

Trump employs other pronouns to support his claim of collectivity and shared responsibility. For instance, the pronouns you and your are also used in this speech to achieve certain political purposes. Let's consider the following example (5): 


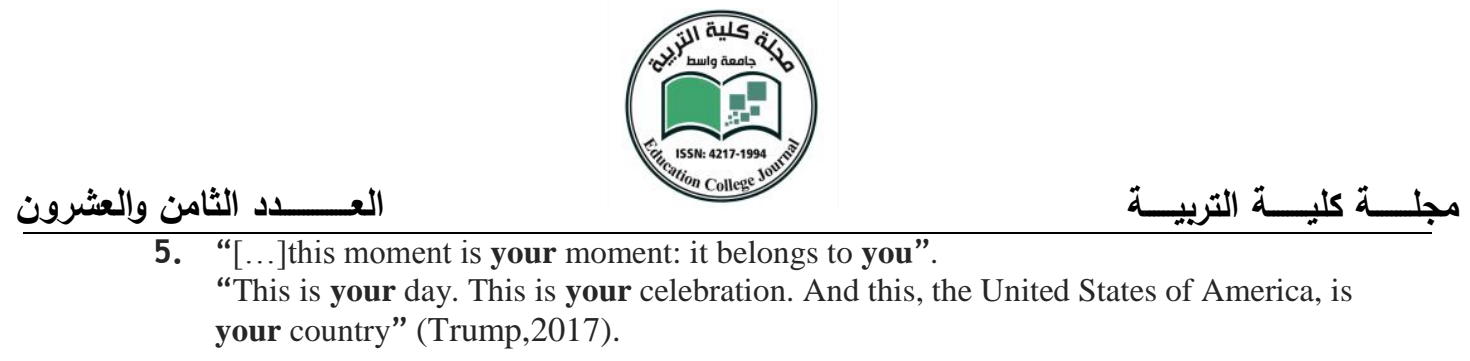

The you and your are generic pronouns used to address not only the audience but the whole nation. In order to get the audience support and acceptance, the message that Trump would like to convey through this use is that his government belongs to and is the representative of the whole nation. It is a call for unification and an attempt to rally the whole American nation behind him. Another example is found in (6) below:

6. "You will never be ignored again. Your voice, your hopes, and your dreams will define our American destiny. And your courage and goodness and love will forever guide us along the way"(Trump,2017).

In this example, Trump aims to persuade the audience that they will be the real rulers of their country. He introduces himself, his party and his administration as representing and defending the interests of every citizen in the USA. He tries to encourage hope among the Americans by telling them that they will never be ignored. In this context, Trump presents himself as a good politician who cares about his people hopes, dreams...etc.

\section{b. The unification vis-à-vis the negative portraying of others}

The third-person plural pronoun they is used in two forms: in example (7) below, it is used to describe positively the American children as they share everything and live in the same country.

7. "they look up at the same night sky, they fill their heart with the same dreams, and they are infused with the breath of life by the same almighty Creator" (Trump, 2017).

The pronoun they is employed, In (7), to stress the idea that all the Americans are equal and should always be unified. It is a call for unification to get the audience support, acceptance and applause.

In example (8) below. The possessive pronoun their is designed to defend the Americans' right in a better life. 


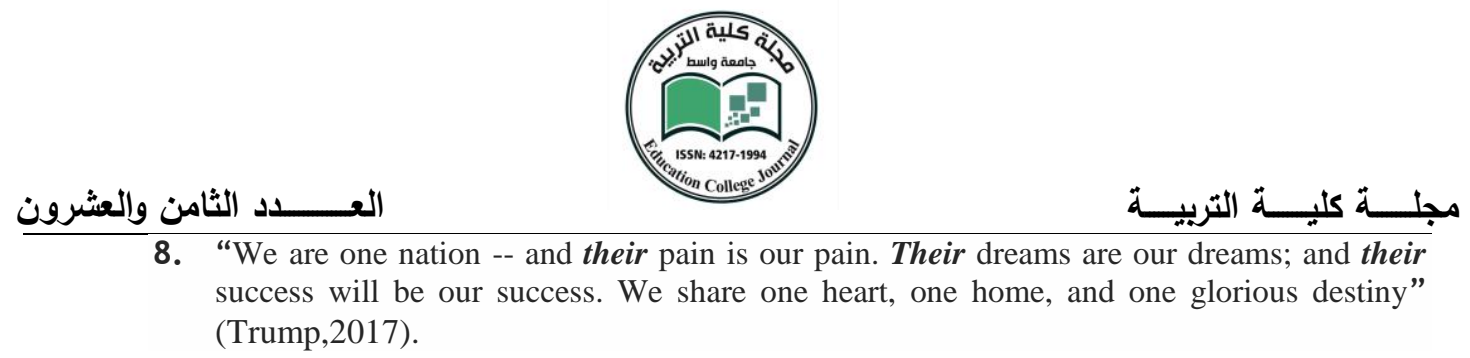

Trump, in this context, attempts to project himself as the national leader who cares about every citizen in America. He would like to encourage hope among the Americans by telling them that his government belongs to them, and it will work to stop their pain, realize their dreams and help them to achieve success because they live in one country and share one destiny.

On the other hand, the repetition of the possessive pronoun their, as it is shown in example (9), is designed to portray the opposition or the exadministration negatively.

9. "Their victories have not been your victories; their triumphs have not been your triumph" (Trump,2017).

The choice of pronoun in Trump's speech is based on presenting himself in a positive light. He uses the possessive pronoun their in (9) as a distancing strategy and to show his ideological differences. Their is employed to provide a negative description of the opponents or the ex-administration and to make them appear less suitable leaders than Trump himself, because everything they have achieved, in Trump's view, was for their own interest and it was not for the sake of their people and their country. Trump would like through this portraying to persuade people that his administration will be different of Obama's; it will realize what the Americans are looking for.

\section{c. Commitment and personal responsibility}

The pronoun $\boldsymbol{I}$ is mostly employed to make general statements. However, politicians usually avoid using the $\boldsymbol{I}$ as it has "distancing and negative effects"(Karapetjana, 2011:43).

The use of the first-person singular pronoun $\boldsymbol{I}$, as it is shown in example (10) below, provides Trump with the possibility to show commitment and personal responsibility.

10. "I will fight for you with every breath in my body -- and $\mathbf{I}$ will never, ever let you down" (Trump,2017) 


\section{العــــــد الثامن والعشرون}

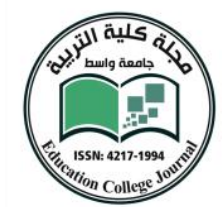

In comparison to the pronoun we, the first- person singular pronoun $\boldsymbol{I}$ is only repeated three times. In all these cases, Trump doesn't talk about himself rather he uses $I$ to introduces himself as the loyal patriot who will fight and defend the American nation. In short, The pronoun $\boldsymbol{I}$ is used by Trump to express his commitment and personal responsibility as the president of the USA.

\section{Phrasal repetition}

Politicians often use different techniques as effective strategies to convey their ideologies and ideas. A skillful political speaker, with the appropriate employment of these strategies, can change the opinion of the audience to his/her advantage. In other terms, politicians are absolutely aware of the value of using some important techniques to get the audience support, evoke applause and elicit agreement for their political ideas and views. (Lin, 2011: 474).

The phrasal repetition occurs many times in Trump's speech. "We will” for instance, reached 41. Let's, for instance, consider the following example (11)

11. “we are protected, and we will always be protected".

"We will be protected by the great men and women of our military and law enforcement and, most importantly, we will be protected by God" (Trump,2017).

The phrase "we will" is mainly used to clarify the willingness and the intention of the new administration, represented by president Trump, to perform his political program objectives. The presence of the pronoun $\boldsymbol{w e}$ can be seen as a continuation of the inclusiveness and shared responsibility that Trump keens on deploying throughout his speech. Further, this employment may contribute to simplify the task of comprehension on the listener's part; it would enable the audience to understand the speech easily. 


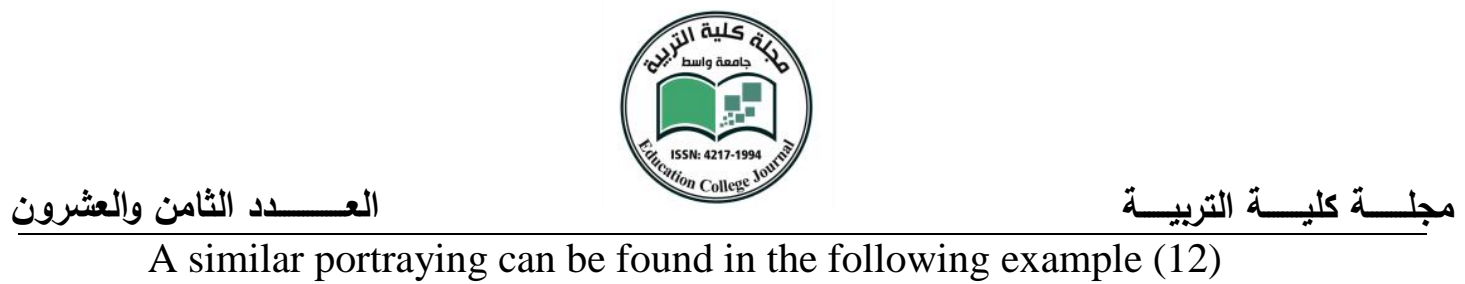

12. "whether we are black or brown or white, we all bleed the same red blood of patriots, we all enjoy the same glorious freedoms, and we all salute the same great American Flag" (Trump,2017).

The word "all" emphasizes the inclusiveness offered by the pronoun we. The repetition of "we all" is used to emphasize unity as well as to create a rhythmic flow and add a sense of cohesion to the speech. In other words, this usage aims at producing a more effective and persuasive speech. In other words, Trump, in (12), is drawing a special attention to emphasize his inclusiveness, as well as helping the audience to process information and understand the speech. Another example (13) occurs in the following excerpt:

13. "This is your day. This is your celebration. And this, the United States of America, is your country"(Trump,2017).

In this example, the phrase "this is" accompanied with the possessive pronoun your are used to emphasize the idea of a shared membership and make it more convincing. Trump seeks to persuade the audience that he is not only a politician but also one of them. He would like to say that his government doesn't belong to the republican party only rather it belongs to every citizen in America.

Another important point to be mentioned here, politicians frequently employ anaphora as a rhetorical device in their addresses to evoke support among the audience and invite applause to their thoughts. (Jasim and Aziz, 2007:5)

The anaphoric repetition, which can be defined as the repetition of a word or a phrase at the beginning of two or more consecutive sentences, clearly appears as one of the main techniques used in Trump's speech by repeating the thematic words and phrases. Trump actually enriches his speech with the employment of the anaphoric repetition to create more convincing and effective speech. Furthermore, anaphora gives the lines, in $(11,12,13)$, a peculiar rhythm that contributes to the increase of the harmony of speech. 


\subsection{Clausal repetition}

When a speaker would like to emphasize the importance of something, s/he may repeat some words, phrases or sentences several times within his/her speech so that they can be remembered by the audience.

Clausal repetition is also one of the techniques employed in Trump's speech. An illustrative example is found in (14) below:

14. “We will bring back our jobs. We will bring back our borders. We will bring back our wealth. And we will bring back our dreams" (Trump,2017)..

The presence of both pronouns we and our in these sentences reminds us about the inclusiveness and shared responsibility that Trump establishes with his audience by the extensive use of these two pronouns throughout his speech. In addition, repetition serves here as "cohesive agent" Halliday and Hasan (1976: 592) that links sentence to each other. Further, repetition, in this excerpt, is employed to add more excitement that can make the speech more convincing for the audience.

Another example (15) of phrasal repetition occurs in the following excerpt:

15. “There should be no fear -- we are protected, and we will always be protected. We will be protected by the great men and women of our military and law enforcement and, most importantly, we will be protected by God" (Trump,2017).

Repetition is used, in (15), to achieve emphasis and rhythm in the developing of ideas to influence the audience feeling. It is employed as a persuasive strategy to convince the audience that America is strong and is protected.

The same strategy is used in the final part of Trump's discourse, example

16. "Together, We will make America strong again".

"We will make America wealthy again".

"We will make America proud again".

"We will make America safe again".

"And yes, together, we will make America great again" 


\section{العـــــــد الثامن والعشرون}

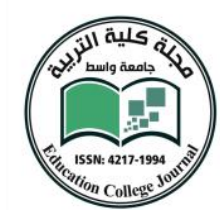

The repetition of these sentences creates a poetic style that can have an immediate emotional impact on the audience. That can clearly be seen in the warm applause which immediately started after the last sentence. In addition, by repeating the word "America" in each sentence, as demonstrated in (16), Trump tries to show his affiliation and loyalty to America and the American people.

Furthermore, the use of symploce; the combination of both anaphora and epiphora by repeating words or phrases at both the beginning and end of successive clauses undoubtedly contributes to the rhythmic organization of speech due to an increase in the intonation and sound identity at both sides particularly at the end of these sentences, which makes these sentences remarkable and memorable.

By the combination of different devices and techniques in one excerpt, Trump displays his eloquence to deliver a political speech which will be memorable by his audience.

\section{Conclusions}

The extensive use of repetition, by president Trump, serves various functions. As a significant technique, repetition is used in Trump speech to convey his political message and persuade people of his political views and thoughts.

The analysis has shown also that the different types of repetition have been employed in Trump's address to support and reinforce his political ideologies. It is used to encourage hope, patriotism and harmony among the Americans. The extensive repetition of pronouns such as we, our, you, your is designed to reflect inclusiveness and shared responsibility with the audience. Repetition is also employed as a unification strategy that has both an emotional and persuasive power on the audience.

Moreover, in combination with other devices such as anaphora and epiphora, repetition is used as a cohesive agent to create a rhythmic flow and add a sense of cohesion to the speech.

It is therefore pertinent to conclude that what is prominent about Trump's use of repetition is that it is used to create a homogenous sphere and to rally the whole American nation behind him. 


\section{REFERENCES}

Allen, W. (2007). Australian Political Discourse: pronominal choice in campaign speeches. In Mary Laughren \& Ilana Mushin (eds.) Conference of the Australian Linguistic Society.

Bramley, N. R. (2001). Pronouns of Politics: the use of pronouns in the construction of 'self' and 'other' in political interviews. https:// openresearch-

repository.anu.edu.au/bitstream/1885/46225/5/01 front.pdf 20.3.2017.

Campbell, K. and K. Jamieson (1985). Inaugurating the Presidency, In Presidential Studies Quarterly, Vol. 15(2), Priorities and Strategies in Foreign Policy: 1985-1989 (Spring,1985), pp. 394- 411.Published by: Wiley on behalf of the Center for the Study of the Presidency and Congress

Charteris-Black, J. (2005). Corpus Approaches to Critical Metaphor Analysis. New York: Palgrave MacMillan.

Chilton, P. (2004). Analysing Political Discourse: Theory and Practice. London:

Routledge.

De Fina, A. (1995). Pronominal choice, identity, and solidarity in political discourse. In Interdisciplinary Journal for the Study of Discourse Text, 15(3), 379-410.

Dlugan, A. (2009). Speech Analysis: I Have a Dream-Martin Luther King $\quad$ Jr. Retrieved on 11612012, available at: http://www.sixminutes. dlugan.com Ispeechanalysis-dream-martin-luther-kingl.10.3.2017.

Durān, J. (2008). The Analysis of Political Discourse Applied to Bush's and Kerry's Speeches. In Nina Nørgaard (ed.) Systemic Functional Linguistic in Use. Odense Working Papers in Language and Communication. Vol.29(1): 267-282.

Fairclough, N. (1989). Language and Power. London: Longman.

(1992). Discourse and Social Change. Cambridge: Polity Press.

Farghal, M. \& Shunnaq, A. (1999) Translation with Reference to English and Arabic. Irbid: Dar Al-Hilal for Translation.

Gee, P. (1999). An Introduction to Discourse Analysis: Theory and Method. London and New York: Routledge

Halliday, M. \& R. Hasan, (1976). Cohesion in English. London: Longman. 
العــــــد الثامن والعشرون

Inigo-Mora, I. (2013). Pronominal Choice as an Interpersonal Strategy. In International Journal of Contemporary http://www.aijcrnet.com/journals/Vol_3_No_3_March _2013/3.

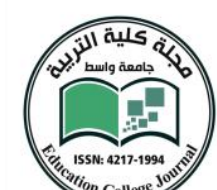

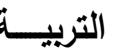

American

Research

pdf 2.4.2017

Jasim, M. \& Aziz, F. (2007). No Repetition Where None Intended: A Stylistic Study of Repetition as a Cohesive Signal In Samuel Beckett's Waiting for Godot. In Journal of the College of Arts. University of Basrah No. 43.pp.1-19.

Johnstone, B. (1994). "Repetition in discourse: a dialogue". In B. Johnstone (ed.) Repetition in Discourse: Interdisciplinary Perspectives, 1 Ablex Advances in Discourse Processes Norwood, New Jersey: 2-23.

Jørgensen, M. and L. Phillips (2002). Discourse Analysis as Theory and Method. London and New Delhi: Sage Publications.

Karapetjana, I. (2011). Pronominal Choice in Political Interviews. In Baltic Journal of English Language, Literature and Culture Vol.1, 2011: 36-45

Kaufer, D., S. Bulter, B. Bulter \& J. Collins (2004). The power of Words: Unveiling the Speaker and Writer's Hidden Craft. New Jersey and London: Lawrence Erlbaum Associates Publishes.

Kawin, B. (1972). Telling It Again and Again: Repetition in Literature and $\quad$ Film. London: Cornell University Press.

Kim, H. (2002). The form and function of next-turn repetition in English conversation. In Language Research 38(1), 51-81

Liu, F. (2012). Genre Analysis of American Presidential Inaugural Speech. In Theory and Practice in Language Studies, Vol. 2, No. 11, pp. 2407-2411, Finland: Academy Publisher press.

Orwell, G. (1968) Politics and the English Language. In Sonia Orwell and Jan Angos (eds.) the Collection Essays, Journalism and Letters of George Orwell, Vol.4, ed. 1, 40-127.

Oxford Advanced Learner Dictionary.(2004) ed.S.v. "Repetition". Oxford University Press

Schiffrin, D \& Tannn, D. (2003) The Handbook of Discourse Analysis. New York : Blackwell Publishing Ltd.

Seidel, G. (1985). Political Discourse Analysis. London: Academic Press. 


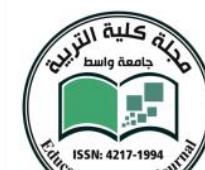

Tannen, D. (2007). Talking Voices: Repetition, Dialogue and Imagery in Conversation. Cambridge: Cambridge University Press.

Trump. D. (2017). Presidential Inauguration Address. http://edition.cnn.com/2017/01/20/politics/trump-inaugural-address/ 30.3.2017

Van Dijk, T. (1997).“What is Political Discourse Analysis?” In Jan Blommaert and Chris Bulcaen (Eds.) Belgian Journal of Linguistics 11, pp. 11-52.

Wales, K. (1996). Personal Pronouns in Present-day English. Cambridge: University Press

Wen Lin, Ch. (2011). The Study of Political Language: A Brief Overview of Recent Research. In Chia-Nan Annual Bulletin Vol.37, PP.471-485,2011

Wilson, J. (1990). Politically Speaking. The Pragmatic Analysis of Political Language. Oxford: Basil Blackwell.

(2003). Political discourse. (eds.) Schiffrin, D and Tannn, D. (2003)The Handbook of Discourse Analysis. Blackwell
Publishing
Ltd.: New York. 


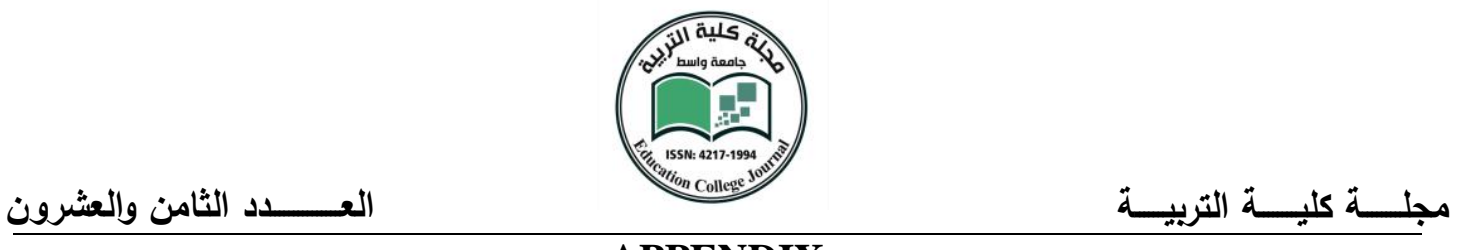

\section{APPENDIX}

\section{Donald J. Trump's Inaugural Address January $20^{\text {th }}, 2017$}

Chief Justice Roberts, President Carter, President Clinton, President Bush, President Obama, fellow Americans, and people of the world: Thank you.

We, the citizens of America, are now joined in a great national effort to rebuild our country and to restore its promise for all of our people.

Together, we will determine the course of America and the world for many many years to come.

We will face challenges. We will confront hardships. But we will get the job done.

Every four years, we gather on these steps to carry out the orderly and peaceful transfer of power, and we are grateful to President Obama and First Lady Michelle Obama for their gracious aid throughout this transition. They have been magnificent. Thank you

Today's ceremony, however, has very special meaning. Because today we are not merely transferring power from one administration to another, or from one party to another -- but we are transferring power from Washington, D.C. and giving it back to you, the American People.

For too long, a small group in our nation's Capital has reaped the rewards of government while the people have borne the cost. Washington flourished -- but the people did not share in its wealth. Politicians prospered -- but the jobs left, and the factories closed.

The establishment protected itself, but not the citizens of our country. Their victories have not been your victories; their triumphs have not been your triumphs; and while they celebrated in our nation's capital, there was little to celebrate for struggling families all across our land.

That all changes -- starting right here, and right now, because this moment is your moment: it belongs to you.

It belongs to everyone gathered here today and everyone watching all across America. This is your day. This is your celebration. And this, the United States of America, is your country. 
What truly matters is not which party controls our government, but whether our government is controlled by the people. January 20th 2017 , will be remembered as the day the people became the rulers of this nation again. The forgotten men and women of our country will be forgotten no longer.

Everyone is listening to you now.

You came by the tens of millions to become part of a historic movement the likes of which the world has never seen before. At the center of this movement is a crucial conviction: that a nation exists to serve its citizens.

Americans want great schools for their children, safe neighborhoods for their families, and good jobs for themselves. These are the just and reasonable demands of righteous people and a righteous public.

But for too many of our citizens, a different reality exists: Mothers and children trapped in poverty in our inner cities; rusted-out factories scattered like tombstones across the landscape of our nation; an education system flush with cash, but which leaves our young and beautiful students deprived of all knowledge; and the crime and the gangs and the drugs that have stolen too many lives and robbed our country of so much unrealized potential.

This American carnage stops right here and stops right now.

We are one nation -- and their pain is our pain. Their dreams are our dreams; and their success will be our success. We share one heart, one home, and one glorious destiny.

The oath of office I take today is an oath of allegiance to all Americans.

For many decades, we've enriched foreign industry at the expense of American industry; subsidized the armies of other countries while allowing for the very sad depletion of our military; we've defended other nation's borders while refusing to defend our own; and spent trillions and trillions of dollars overseas while America's infrastructure has fallen into disrepair and decay.

We've made other countries rich while the wealth, strength, and confidence of our country has disappeared over the horizon.

One by one, the factories shuttered and left our shores, with not even a thought about the millions and millions of American workers that were left behind. 


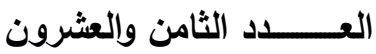

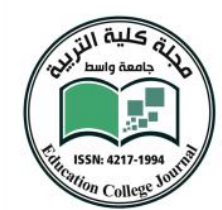

The wealth of our middle class has been ripped from their homes and then redistributed across the entire world.

But that is the past. And now we are looking only to the future. We assembled here today are issuing a new decree to be heard in every city, in every foreign capital, and in every hall of power.

From this day forward, a new vision will govern our land.

From this moment on, it's going to be only America First. America first

Every decision on trade, on taxes, on immigration, on foreign affairs, will be made to benefit American workers and American families. We must protect our borders from the ravages of other countries making our products, stealing our companies, and destroying our jobs. Protection will lead to great prosperity and strength.

I will fight for you with every breath in my body -- and I will never, ever let you down.

America will start winning again, winning like never before.

We will bring back our jobs. We will bring back our borders. We will bring back our wealth. And we will bring back our dreams.

We will build new roads, and highways, and bridges, and airports, and tunnels, and railways all across our wonderful nation.

We will get our people off of welfare and back to work -- rebuilding our country with American hands and American labor.

We will follow two simple rules: Buy American and hire American.

We will seek friendship and goodwill with the nations of the world -- but we do so with the understanding that it is the right of all nations to put their own interests first.

We do not seek to impose our way of life on anyone, but rather to let it shine as an example. We will shine for everyone to follow.

We will reinforce old alliances and form new ones -- and unite the civilized world against radical Islamic terrorism, which we will eradicate completely from the face of the Earth. 
At the bedrock of our politics will be a total allegiance to the United States of America, and through our loyalty to our country, we will rediscover our loyalty to each other.

When you open your heart to patriotism, there is no room for prejudice. The Bible tells us, "How good and pleasant it is when God's people live together in unity."

We must speak our minds openly, debate our disagreements honestly, but always pursue solidarity.

When America is united, America is totally unstoppable.

There should be no fear -- we are protected, and we will always be protected.

We will be protected by the great men and women of our military and law enforcement and, most importantly, we will be protected by God.

Finally, we must think big and dream even bigger.

In America, we understand that a nation is only living as long as it is striving.

We will no longer accept politicians who are all talk and no action -- constantly complaining but never doing anything about it.

The time for empty talk is over. Now arrives the hour of action.

Do not allow anyone to tell you that it cannot be done. No challenge can match the heart and fight and spirit of America.

We will not fail. Our country will thrive and prosper again.

We stand at the birth of a new millennium, ready to unlock the mysteries of space, to free the Earth from the miseries of disease, and to harness the energies, industries and technologies of tomorrow.

A new national pride will stir our souls, lift our sights, and heal our divisions.

It is time to remember that old wisdom our soldiers will never forget: that whether we are black or brown or white, we all bleed the same red blood of patriots, we all enjoy the same glorious freedoms, and we all salute the same great American Flag. 
And whether a child is born in the urban sprawl of Detroit or the windswept plains of Nebraska, they look up at the same night sky, they fill their heart with the same dreams, and they are infused with the breath of life by the same almighty Creator.

So to all Americans, in every city near and far, small and large, from mountain to mountain, and from ocean to ocean, hear these words:

You will never be ignored again.

Your voice, your hopes, and your dreams will define our American destiny. And your courage and goodness and love will forever guide us along the way.

Together, We will make America strong again.

We will make America wealthy again.

We will make America proud again.

We will make America safe again.

And yes, together, we will make America great again. Thank you. God bless you. And God bless America 
وظيفة التكرار في خطاب تتصيب الرئيس الامريكي دونالد ترامب التبلة

مجلــــة كليــــة التربيـــة

دراسة تحليلية

م.م. حبيب محسن عريف السعيدي

كلية التربية ، جامعة القادبية

\section{ملخص البحث}

يعتبر الخطاب السياسي واحدا من أكثر أنواع الخطابات إثكالية لأنه يتميز عادة باستخدام اساليب

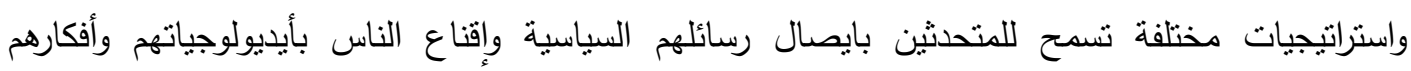
الخاصة بهم.

خطابات التتصيب للرئاسة الأمريكية هي شكل من أثنال الخطاب السياسي التي تتميز باحتوائها على

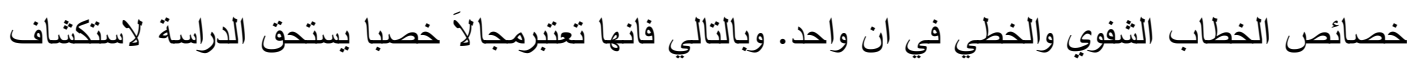
بعض الخصائق التي يتميز بها هذا النوع من الخطاب.

هذه الدراسة التحليلية تبحث في وظيفة التكرار في خطاب التتصيب للرئيس الامريكي الـ 0 ـ دونالد ج. ترمب

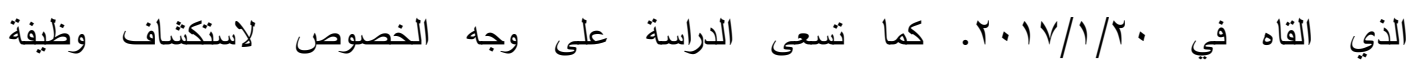
تكرارالضمائروالعبارات والجمل التي حرص ترامب على تكرارها بكثر في خطابه.

وقد بينت الدراسة من خلال التحليل أن التكرار قد استخدم كاستراتيجية اساسية في خطاب نرامب ليعكس

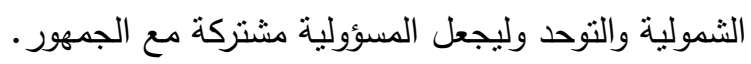

كلمات مفتاحية: دونالد جي نرامب، الخطاب السياسي، خطاب التتصيب، الثمولية . 